\title{
Autonomy, Efficiency and Effectiveness-Opportunities for Higher Education: A Pilot Study
}

\author{
Veronika Kupriyanova, Enora Bennetot Pruvot, and Thomas Estermann
}

\section{Introduction}

Autonomy and accountability are among the key topics that have been shaping the European higher education landscape over the past years. Recently, these issues have acquired renewed importance for both higher education practitioners and academia in the context of the intensifying public discourse on efficiency and effectiveness and the related targets that funders and policy-makers set for universities across Europe in view of declining public funds and other external pressures (e.g. Estermann and Nokkala 2009; Estermann 2017; Salerno 2003). Efficiency and effectiveness are also part of the EU priorities for higher education and research, reflected in the EU Strategic Framework for Education and Training until 2020, the Renewed EU Agenda for Higher Education and the Reinforced European Research Area Partnership for Excellence and Growth. Autonomy has been discussed in several theoretical and practiceoriented studies as a pre-condition for the capacity of higher education institutions to be efficient and effective (e.g. Levacic 2002; Estermann and Kupriyanova 2019). Previous research concluded that "universities must be autonomous and able to independently shape their governance structures within agreed accountability frameworks in order to be able to react more effectively to external challenges, address social and economic needs, and manage resources in a more strategic, efficient and effective way" (Estermann and Kupriyanova 2019: 9).

While there has been some general acknowledgement of the link between autonomy and efficiency of universities, there has been little research so far on the internal

\footnotetext{
V. Kupriyanova $(\varangle) \cdot$ E. Bennetot Pruvot $\cdot$ T. Estermann European University Association, Brussels, Belgium

e-mail: veronika.kupriyanova@eua.eu

E. Bennetot Pruvot

e-mail: enora.pruvot@eua.eu

T. Estermann

e-mail: thomas.estermann@eua.eu 
mechanisms of this relationship, particularly, considered through the prism of institutional autonomy in various fields, such as organisation, staff, finances and academic matters.

This paper aims to close this gap with a pilot study aimed at testing-with a small group of European higher education professionals-a new methodological approach to assess the impact of autonomy on both effectiveness and efficiency of higher education institutions based on the four autonomy dimensions and the related indicators included in the University Autonomy Scorecard. ${ }^{1}$

The goal of this research direction, which is certainly not limited to this paper, is to offer a more nuanced understanding of how national regulatory frameworks affect the capacity of institutions to deliver on their missions in an efficient and effective way. Such new knowledge can be useful to inform discussions between public authorities and the university sector and to support leaders and managers of higher education institutions in the development of institutional efficiency strategies.

In this paper, we aim to launch the debate on several major questions, which will require further investigation: What mechanisms connect regulatory frameworks to efficient and effective university management? Which elements (i.e. dimensions and indicators) of autonomy have the greatest impact on efficiency and effectiveness of universities? How can (greater) autonomy be converted into efficiency and effectiveness in the higher education context? And, finally, what is the role of accountability in this constellation of autonomy, efficiency and effectiveness?

\section{Methodology and Scope}

\subsection{Research Framework}

The concept of autonomy in this study is based on a multidimensional approach developed by the European University Association (EUA) for its University Autonomy Scorecard. This approach distinguishes between four dimensions of autonomy: organisational, financial, staffing and academic. Each autonomy dimension is associated with a set of indicators (Table 1). For example, organisational autonomy refers to the procedures and criteria for the selection and dismissal of the executive head, the composition of governing bodies and the capacity to design academic structures. Financial autonomy involves flexibility of higher education institutions in managing public funds and estates and defining other financial processes applied for tuition fees (Bennetot Pruvot and Estermann 2017). For the purpose of the present analysis, the Autonomy Scorecard indicators for financial autonomy include, in addition, the capacity for universities to engage in joint procurement, given the strategic nature of this field in relation to institutional efficiency (Estermann and Kupriyanova 2019).

\footnotetext{
${ }^{1}$ University Autonomy Scorecard. www.university-autonomy.eu, accessed February 12, 2020.
} 
Table 1 Autonomy indicators included in the analysis

\begin{tabular}{|c|c|c|c|}
\hline $\begin{array}{l}\text { Organisational } \\
\text { autonomy }\end{array}$ & Financial autonomy & Staffing autonomy & Academic autonomy \\
\hline $\begin{array}{l}\text { Ability to decide on } \\
\text { selection procedure for } \\
\text { the executive head }\end{array}$ & $\begin{array}{l}\text { Ability to decide on } \\
\text { internal allocation of } \\
\text { public funding }\end{array}$ & $\begin{array}{l}\text { Ability to decide on } \\
\text { recruitment } \\
\text { procedures (senior } \\
\text { academic staff) }\end{array}$ & $\begin{array}{l}\text { Capacity to decide on } \\
\text { overall student } \\
\text { numbers }\end{array}$ \\
\hline $\begin{array}{l}\text { Ability to decide on } \\
\text { selection criteria for } \\
\text { the executive head }\end{array}$ & $\begin{array}{l}\text { Capacity to keep } \\
\text { financial surplus }\end{array}$ & $\begin{array}{l}\text { Ability to decide on } \\
\text { recruitment } \\
\text { procedures (senior } \\
\text { administrative staff) }\end{array}$ & $\begin{array}{l}\text { Ability to select } \\
\text { students }\end{array}$ \\
\hline $\begin{array}{l}\text { Ability to decide on } \\
\text { dismissal procedure of } \\
\text { the executive head }\end{array}$ & $\begin{array}{l}\text { Capacity to borrow } \\
\text { money }\end{array}$ & $\begin{array}{l}\text { Ability to decide on } \\
\text { promotions (senior } \\
\text { academic staff) }\end{array}$ & $\begin{array}{l}\text { Ability to introduce } \\
\text { programmes }\end{array}$ \\
\hline $\begin{array}{l}\text { Ability to set term of } \\
\text { office of the executive } \\
\text { head }\end{array}$ & $\begin{array}{l}\text { Ability to own real } \\
\text { estate }\end{array}$ & $\begin{array}{l}\text { Ability to decide on } \\
\text { promotions (senior } \\
\text { administrative staff) }\end{array}$ & $\begin{array}{l}\text { Ability to terminate } \\
\text { programmes }\end{array}$ \\
\hline $\begin{array}{l}\text { Ability to include } \\
\text { external members in } \\
\text { governing bodies }\end{array}$ & $\begin{array}{l}\text { Ability to sell real } \\
\text { estate }\end{array}$ & $\begin{array}{l}\text { Ability to decide on } \\
\text { salaries (senior } \\
\text { academic staff) }\end{array}$ & $\begin{array}{l}\text { Ability to choose the } \\
\text { language of instruction }\end{array}$ \\
\hline $\begin{array}{l}\text { Ability to select } \\
\text { external members in } \\
\text { governing bodies }\end{array}$ & $\begin{array}{l}\text { Ability to engage in } \\
\text { joint procurement }\end{array}$ & $\begin{array}{l}\text { Ability to decide on } \\
\text { salaries (senior } \\
\text { administrative staff) }\end{array}$ & $\begin{array}{l}\text { Capacity to select QA } \\
\text { mechanisms and } \\
\text { providers }\end{array}$ \\
\hline $\begin{array}{l}\text { Capacity to decide on } \\
\text { academic structures }\end{array}$ & $\begin{array}{l}\text { Ability to set the level } \\
\text { of tuition fees for } \\
\text { national/EU students }\end{array}$ & $\begin{array}{l}\text { Ability to decide on } \\
\text { dismissals (senior } \\
\text { academic staff) }\end{array}$ & $\begin{array}{l}\text { Capacity to select QA } \\
\text { mechanisms and } \\
\text { providers }\end{array}$ \\
\hline $\begin{array}{l}\text { Capacity to create } \\
\text { legal entities }\end{array}$ & $\begin{array}{l}\text { Ability to set the level } \\
\text { of tuition fees for } \\
\text { non-EU students }\end{array}$ & $\begin{array}{l}\text { Ability to decide on } \\
\text { dismissals (senior } \\
\text { administrative staff) }\end{array}$ & $\begin{array}{l}\text { Ability to design } \\
\text { content of degree } \\
\text { programmes }\end{array}$ \\
\hline
\end{tabular}

One should note that the current University Autonomy Scorecard does not include any indicators connected to research autonomy. When the original methodology was developed in 2009, the ability to decide on the areas, scope, aims, and methods of research was considered as a significant part of academic autonomy but also an area essentially underpinned by academic freedom and, therefore, enforced throughout all European countries as one of the key pillars and fundamental values in academia (Estermann and Nokkala 2009). This remains one of the methodological limitations for this study, particularly for the analysis of the impact of autonomy on the effectiveness of higher education institutions.

The concepts of efficiency and effectiveness are analysed within a theoretical framework designed as part of the USTREAM project. ${ }^{2}$ This multidimensional approach considers efficiency, effectiveness and value for money tightly linked and

\footnotetext{
2"Universities for Strategic, Efficient and Autonomous Management" (2016-2019), project supported by the European Commission under the Erasmus+ Programme. www.eua.eu/101-projects/ 607-ustream.html, accessed February 12, 2020.
} 
equally important in the higher education context and refers to the convergence of activities and processes at various levels (system, sector and institutional) and in different areas (strategic governance, operational management and academic matters) (Estermann and Kupriyanova 2019).

These methodological approaches facilitate an analysis of the impact that autonomy frameworks can have on efficiency at various levels of higher education. For instance, financial and academic autonomy provisions, such as the capacity to decide on student numbers or set tuition fees, define the overall competition and collaboration modalities at the system level, whereas more specific provisions, such as the ability to engage in joint procurement, underpin sector-level opportunities for economies of scale. In this study, we focus primarily on the impact of various autonomy provisions on the efficiency and effectiveness of individual institutions.

For the purpose of this study, the USTREAM-based multidimensional efficiency framework has been completed with principles and practices of Lean and Six Sigma which have been successfully applied to the higher education context in previous studies (e.g. Antony 2017; Balzer 2010; Balzer et al. 2015; Doman 2011).

In this context, efficiency of higher education institutions is understood as the capacity to achieve financial and other gains through optimised institutional use of resources and management processes (i.e. waste elimination and cycle time reduction in LEAN terms). Effectiveness is viewed as the capacity to achieve the outcomes expected from the institutional vision, mission and the corresponding strategies and action plans (i.e. focus on what is critical to the actor according to the Six Sigma approach).

Accountability is another concept discussed in this paper in light of the key findings on the impact of autonomy on efficiency and effectiveness. It is understood as "a relationship between an actor and a forum, in which the actor has an obligation to explain and to justify his or her conduct, the forum can pose questions and pass judgement, and the actor may face consequences" (Bovens 2006 : 9).

This concept is included in our analysis for two reasons:

(a) as a mechanism to ensure checks and balances vis-à-vis institutional autonomy and

(b) as an enabler of efficiency and effectiveness of higher education institutions, "forcing them to examine their own operations critically, and by subjecting them to critical review from outside" (Trow 1996: 3).

In this paper, we explore the links to both formal and voluntary accountability (i.e. "trust-based" accountability Trow 1996 along the lines of "corporate social responsibility" Jongbloed et al. 2008) towards both external and internal stakeholders.

In our theoretical model, accountability is a pre-condition for autonomy, providing a system of checks and balances in the university context. Coupled with accountability, autonomy serves as an enabler for efficiency and effectiveness. The latter, in turn, helps implement autonomy and accountability in practical terms (Fig. 1). 


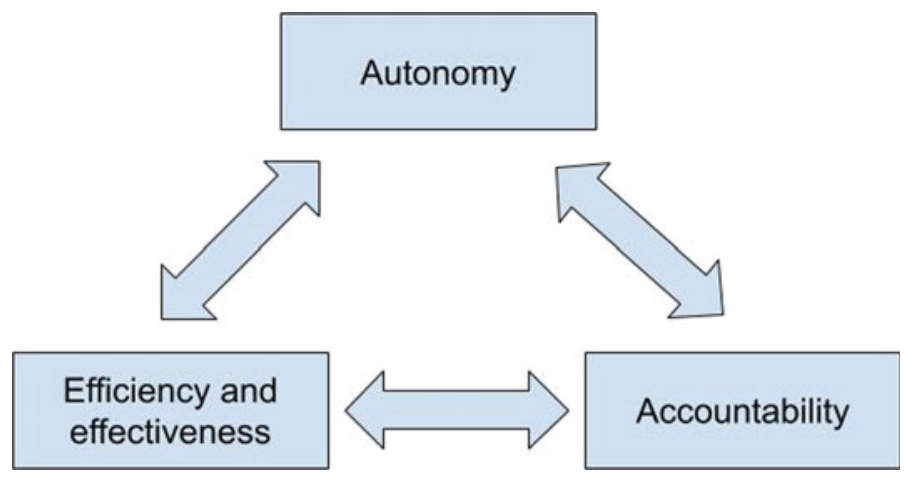

Fig. 1 Autonomy and accountability in practical terms

\subsection{Research Method}

Our study relies on the conceptual frameworks developed by EUA as part of its work on governance, funding and efficiency, the knowledge acquired in previous focus groups $^{3}$ and the expert assessment of the impact of various autonomy dimensions and factors on efficiency and effectiveness. In total, 12 experts from 12 countries in Europe (Austria, Belgium, Finland, Iceland, Italy, Latvia, Lithuania, Netherlands, Poland, Portugal, Romania, Sweden and Switzerland) provided their analytical input to our pilot study in autumn 2019. The experts were selected based on their professional experience in top university management (vice-rector and head of administration level). Consideration was also given to geographic and institutional diversity of the sample.

The experts were invited to assign a score between 1 (lowest impact) and 5 (highest impact) to each autonomy indicator (31 in total), to assess their respective impact on efficiency, from the perspective of resources and processes. The estimates assigned by the experts to resources and processes were added up to achieve one combined score for efficiency. The experts were also requested to rate the impact of these indicators on effectiveness, from the viewpoint of the expected outcomes, by using the same scale.

Concretely, they had to assess how the ability for the institution to do A, B or C has:

(i) (1-5) degree of impact on efficiency from the perspective of costs;

(ii) (1-5) degree of impact on efficiency from the perspective of processes; and

(iii) (1-5) degree of impact on effectiveness (the ability of the institution to achieve its core missions and goals).

\footnotetext{
${ }^{3}$ Peer learning and national policy activities organised under the EU-funded USTREAM project. www.eua.eu/101-projects/607-ustream.html, accessed February 12, 2020.
} 
This assessment was based on their institutional management experience or their "ideal" expectation of such impact (in case there is no significant institutional autonomy in a related field in their system). The experts could provide any qualitative feedback to explain their choices or to share relevant background information.

The average score was calculated for each autonomy indicator by using the arithmetic mean. Standard deviation values were calculated for each case to show the differentiation of experts' views on the topic.

The fact that experts could have different interpretations of the nature of the autonomy indicators included in the study provides another limitation to the applied methodology. Although the descriptions of the autonomy indicators were adapted (simplified) for the purpose of this study, their original purpose was to serve the University Autonomy Scorecard (and thus assess the capacity for institutions to decide on a given set of items). Partly due to this fact, experts found it difficult at times to identify the link between the capacity to decide on a specific item and the impact that having such capacity can have on efficiency and effectiveness, and therefore reported that it had proven difficult to attribute a score to some indicators. The related " $n / a$ " responses were excluded from the analysis.

We also acknowledge some difficulties that experts could have in differentiating between the real impact of autonomy on efficiency and effectiveness based on the situation in their countries and the ideal impact that greater autonomy could have in principle on the topics of study. This aspect shall be clarified specifically with some of the experts.

Furthermore, the applied methodology allowed us to capture the experts' views on some positive influence of autonomy on efficiency and effectiveness. We consider any potential negative effects were marginal and therefore excluded them from the scope of this paper. At this stage, we have not differentiated between short-, mediumor long-term impact that autonomy can have on efficiency or effectiveness, which may be a topic for future studies.

Finally, due to the pilot nature of our study, we could only harvest limited qualitative data from the experts' comments to the questionnaire. While the obtained expert data has proven to be sufficient for testing our methodological approach, presenting some preliminary observations on the topic and opening up new questions for future research, any further investigation will require involving a larger and more diverse sample of respondents to both the questionnaire and a series of expert interviews and focus groups.

\section{Results}

In this section, we present our key findings from three different perspectives. First, we look at the list of the most impactful indicators for each of the four autonomy dimensions in order to identify the most important autonomy drivers in various fields. Second, we analyse the top ten autonomy indicators in terms of their impact on efficiency and effectiveness, respectively, regardless of their specific dimension. 
Finally, we present the results of the aggregate analysis at the level of the autonomy dimensions, with a special focus on those dimensions that have similar impact on both efficiency and effectiveness.

\subsection{Most Impactful Indicators per Each Autonomy Dimension}

Tables 2 and 3 present the most important autonomy indicators for efficiency and effectiveness for each of the four autonomy dimensions ranked on the basis of their mean values. The highest-ranking indicator is indicated for each autonomy dimension. Those indicators that rank highest with respect to both efficiency and effectiveness appear in italics.

The ability to decide on internal allocation of public funding and the ability to design the content of degree programmes emerge from our analysis as the most impor-

Table 2 Autonomy indicators with highest impact on efficiency per each autonomy dimension

\begin{tabular}{l|l|l|l}
\hline Autonomy dimension & $\begin{array}{l}\text { Top ranked autonomy indicators for } \\
\text { efficiency }\end{array}$ & Mean & $\mathrm{Sdv}$ \\
\hline Organisational autonomy & $\begin{array}{l}\text { Capacity to decide on academic } \\
\text { structures }\end{array}$ & 3.50 & 0.87 \\
\hline Academic autonomy & $\begin{array}{l}\text { Ability to design content of degree } \\
\text { programmes }\end{array}$ & 3.83 & 0.80 \\
\hline Financial autonomy & $\begin{array}{l}\text { Ability to decide on internal } \\
\text { allocation of public funding }\end{array}$ & 4.04 & 0.84 \\
\hline Staffing autonomy & $\begin{array}{l}\text { Ability to decide on recruitment } \\
\text { procedures (senior administrative } \\
\text { staff) }\end{array}$ & 4.00 & 0.76 \\
\hline
\end{tabular}

Table 3 Autonomy indicators with highest impact on effectiveness per each autonomy dimension

\begin{tabular}{l|l|l|l}
\hline Autonomy dimension & $\begin{array}{l}\text { Top ranked autonomy indicators for } \\
\text { effectiveness }\end{array}$ & Mean & $\mathrm{Sdv}$ \\
\hline Organisational autonomy & $\begin{array}{l}\text { Ability to decide on selection } \\
\text { procedure for the executive head }\end{array}$ & 3.91 & 0.83 \\
\hline Organisational autonomy & $\begin{array}{l}\text { Ability to decide on selection criteria } \\
\text { for the executive head }\end{array}$ & 3.91 & 0.92 \\
\hline Academic autonomy & $\begin{array}{l}\text { Ability to design content of degree } \\
\text { programmes }\end{array}$ & 4.17 & 0.69 \\
\hline Financial autonomy & $\begin{array}{l}\text { Ability to decide on internal } \\
\text { allocation of public funding }\end{array}$ & 4.08 & 0.76 \\
\hline Staffing autonomy & $\begin{array}{l}\text { Ability to decide on recruitment } \\
\text { procedures (senior academic staff) }\end{array}$ & 4.08 & 0.76 \\
\hline
\end{tabular}


tant indicators for both efficiency and effectiveness within financial and academic autonomy, respectively.

For staffing autonomy, the ability to decide on recruitment of senior administrative staff is more important for efficiency, while the ability to decide on recruitment of senior academic staff is more important for effectiveness.

The ability to decide on the procedure and criteria for the selection of the executive head play a greater role for effectiveness, whereas the capacity to decide on academic structures is more crucial for efficiency, when it comes to various aspects of organisational autonomy.

\subsection{Top 10 Most Impactful Indicators for Efficiency and Effectiveness Across All Autonomy Dimensions}

Figures 2 and 3 introduce the top ten indicators across all autonomy dimensions ranked on the basis of their mean values. Seven indicators out of the two top ten lists are common for both efficiency and effectiveness (featured in light grey in the graphs). Four out of these seven indicators are related to staffing autonomy and reflect the importance of recruitment and promotion procedures adopted for senior academic and administrative staff. Two financial autonomy indicators with a high impact on both efficiency and effectiveness concern the ability to decide on internal allocation of public funding, which is most crucial for efficiency, and to keep financial surplus (i.e., generate financial capacity for strategic priorities). One last common indicator in the field of academic autonomy is associated with the ability to design content of academic programmes (i.e. actively shape the academic offer of the institution). This indicator has the highest importance for effectiveness among all analysed indicators.

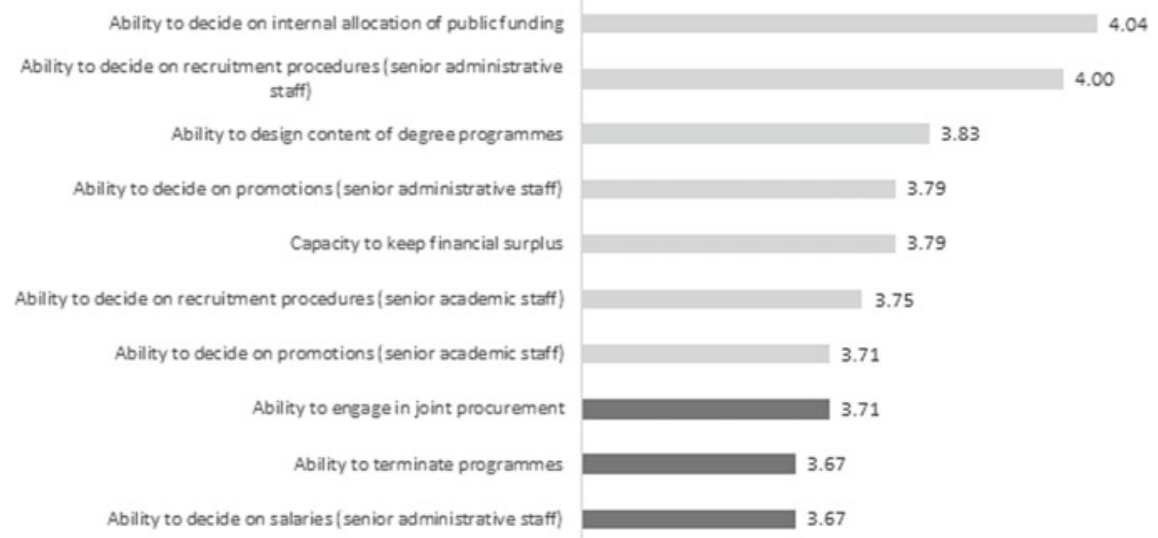

Fig. 2 Top 10 autonomy indicators with the highest impact on efficiency 


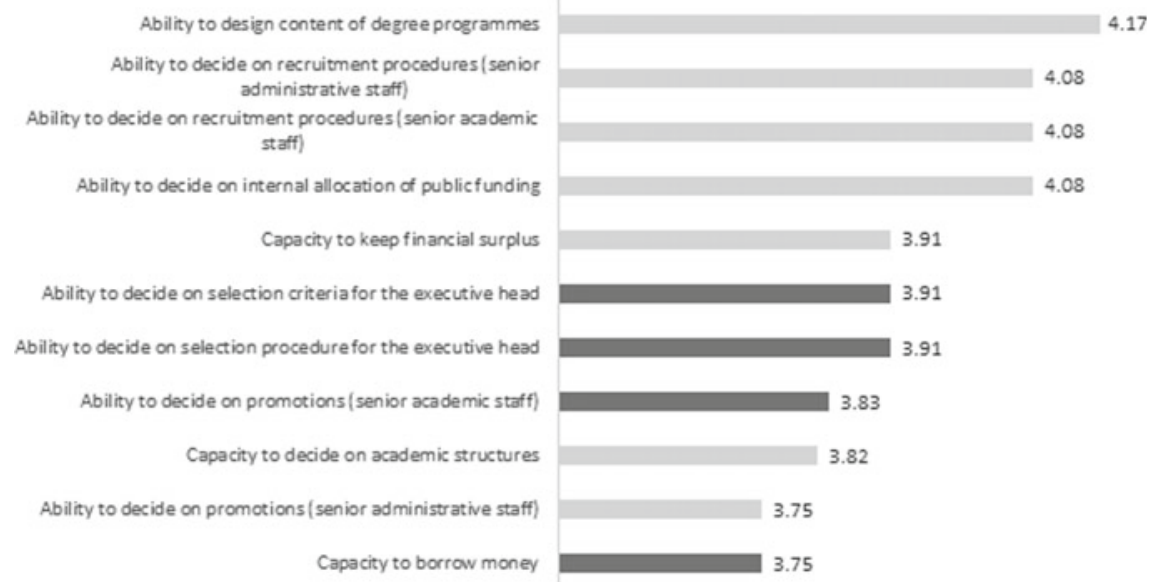

Fig. 3 Top 10 autonomy indicators with the highest impact on effectiveness

\subsection{Autonomy Dimensions with the Highest and Lowest Impact on Efficiency and Effectiveness}

The ranking of various autonomy dimensions in terms of their impact on efficiency and effectiveness is found to be similar for the two concepts under study. Specifically, staffing autonomy is found to have the highest impact on both efficiency $(M=$ $3.56, S D=0.76)$ and effectiveness $(M=3.59, S D=0.98)$ of the four autonomy dimensions under study. Financial autonomy comes as the second most important dimension for both efficiency $(M=3.49, S D=0.92)$ and effectiveness $(M=3.54$, $S D=0.84$ ), followed by academic autonomy, which impact is assessed as slightly more important for effectiveness $(M=3.51, S D=0.76)$ compared to efficiency $(M=3.35, S D=0.64)$. Organisational autonomy is established to have the lowest impact on effectiveness $(M=3.40, S D=0.82)$ and, particularly, efficiency $(M=$ $3.11, S D=0.70)($ Fig. 4).

\subsection{Efficiency Analysis: Resources Versus Processes}

A separate analysis has been run to test whether there are any significant differences in the experts' assessments of impact on the two elements of efficiency (resources and processes). The highest differences ( $>0.3$ point) were identified for five financial autonomy indicators. In particular, the capacity to keep financial surplus, the ability to own and sell real estate and the ability to set the level of tuition fees for both EU and non-EU students have greater impact on resources (by generating/making available additional income) than on processes. Furthermore, in terms of academic auton- 


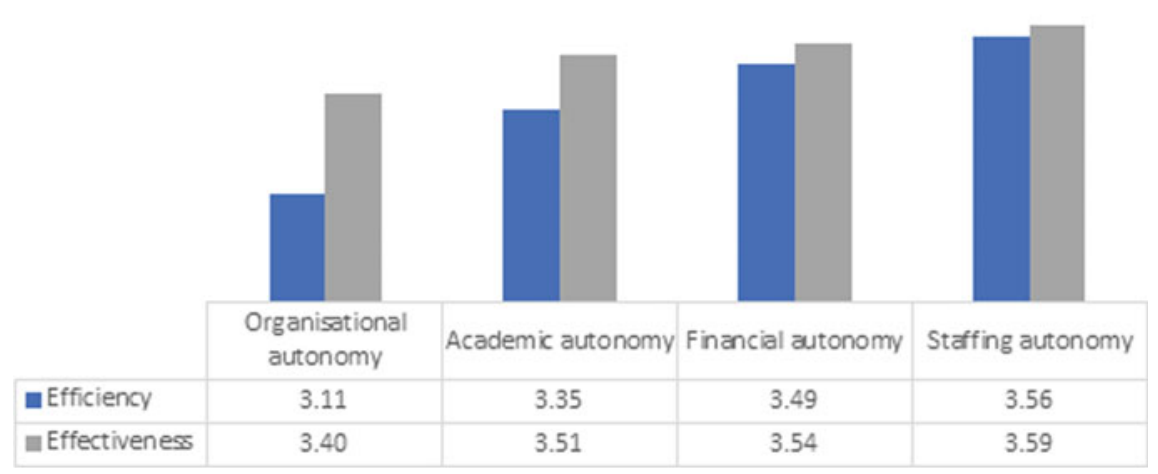

Fig. 4 Cumulative average of each autonomy dimension $(n=12)$

omy, the ability to select student is considered to have greater impact on resources compared to processes.

Conversely, the ability to decide on the selection criteria for the executive head and set her/his term of office as part of organisational autonomy is established to be more important for processes than for resources. Similar differences are found in staffing autonomy: the ability to decide on recruitment procedures of senior academic and administrative staff is considered to have greater impact on processes than on resources.

Elsewhere, the lack of significant discrepancy in the expert responses between resources and processes and the qualitative feedback received suggest that there is either difficulty or limited relevance in seeking to identify the differentiated impact of the autonomy indicators on these two elements of efficiency. This might, however, be due to the experts' understanding of the differences between resources and processes and requires further attention and clarification in the follow-up study.

\section{Discussion}

The obtained results show, most importantly, that efficiency and effectiveness of higher education institutions are framed by the same autonomy dimensions, with staffing and financial autonomy having the highest importance for both topics, and all four dimensions have comparable impacts on both efficiency and effectiveness. This finding suggests that efficiency and effectiveness go hand in hand and can be affected by the same national regulatory provisions. 
In this section, we discuss our findings in light of specific contexts and concrete examples of efficiency and effectiveness gains in order to provide illustration for new opportunities that may arise for higher education institutions from greater autonomy.

\section{Opportunity No 1: Staffing Autonomy for Greater Efficiency and Effectiveness}

Our findings have put staffing autonomy to the forefront in terms of its impact on both efficiency and effectiveness. This finding is not surprising, as the achievement of institutional goals-i.e. effectiveness-largely depends on the competence and motivation of people engaged in the university's core missions and supporting tasks (e.g. Scott 2006). While the ability of universities to recruit senior academic staff and senior administrative staff appears to be most important for effectiveness and efficiency, respectively, the ability to decide on dismissals has much lower importance. This finding refutes one of the widespread assumptions among policy- makers that institutional efficiency amounts to cost-cutting and may be achieved through staff layoffs, considering that salaries often make up the greatest share of the institutions' cost structure. On the contrary, the example of Irish universities shows that staff layoffs may only generate gains in the short term, at the expense of long-term sustainability, strongly affecting the capacity of institutions to deliver on their core mission goals (Estermann et al. 2018). This finding also shows the decision to put a cap on the recruitment of new university staff in several countries such as Denmark, Finland, Ireland and Italy could undermine both efficiency and effectiveness of higher education institutions in these countries (for more details, see EUA Public Funding Observatory reports for 2017 and 2018).

High staffing autonomy can be an important driver for efficiency and effectiveness on two conditions. First, there is sufficient and sustainable public funding of universities in a system, which is crucial to attract and nurture talent. Second, there are proper internal accountability mechanisms that are put by universities in place as part of their "voluntary obligation" to ensure equity, fairness and transparency of all staff related procedures in order to "create and sustain the element of trust" (Trow 1996). Such mechanisms may involve Human Resources (HR) setting out general principles for HR services, recruitment, career paths, leadership and development, recognition and reward as well as positive working environment; thoroughly documented institutional policies (e.g. role profiles, progression processes guidance) and other approaches based on sector best practice and collegiality.

\section{Opportunity No 2: Financial Autonomy for Greater Effectiveness}

Our findings point to the strategic importance of financial autonomy, which has high impact not only on efficiency but also on effectiveness. Financial autonomy, particularly the ability to decide on internal allocation of public funding and the capacity to keep surplus, underpins possibilities for institutions to re-invest the efficiency gains from better processes into the core academic tasks.

Other related factors such as flexibility in real estate management and procurement create opportunities to generate efficiencies, for example, by fostering space optimisation initiatives and by establishing purchasing consortia. Although the capacity to act autonomously on these issues seems to have less relevance for effectiveness, 
it supports the ability of universities to redesign their campuses to better serve the evolving needs of learners and other societal actors to accommodate student-centred learning, foster co-creation processes, underpin sustainability and create bridges to local economy.

It is interesting to note that the capacity to sell real estate is considered by the experts as significantly less relevant (for both efficiency and effectiveness) than the capacity to own real estate. A possible interpretation of these findings is that there is no appetite for large-scale, radical operations whereby universities would seek to do away with historical buildings but rather a wish to be able to invest, upgrade and optimise existing assets. However, this argument still needs to be validated on a larger sample, considering a rather high differentiation of expert opinions on the impact of these two indicators, and cross-checked against specific country contexts.

While more flexibility in setting tuition fee levels is clearly linked to systemlevel political choices, it contributes to universities' efforts to diversify their income structure and limit dependency towards public funding. In the systems where universities have margin for manoeuvre to set the level of fees for national (e.g. England ${ }^{4}$ ) or international students, value for money is an important concept viewed as the achievement of economy, efficiency and effectiveness in how the university acquires and uses its resources in order to meet its objectives, particularly in satisfying the needs of students as fee-paying customers (Universities UK 2015).

The EUA Autonomy Scorecard 2017 features only a few higher education systems in Europe that score high in terms of financial autonomy. ${ }^{5}$ This is particularly due to the fact that public authorities regulate tuition fees in many systems in Europe and steer the system through an increased use of funding instruments, which are part of the current financial accountability procedures. In systems with a high degree of financial autonomy, such as England, universities are subject to high accountability requirements. Typically, universities are financially accountable to various funders and taxpayers through multiple financial reporting and auditing requirements at national and European level (in case of EU-funded projects). In most cases, such mechanisms provide sufficient guarantees to the stakeholders and speak in favour of greater flexibility for university financial management. It is, however, important to stress that greater financial autonomy should not serve to compensate for public funding cuts to "equip universities to seek funding elsewhere" (Bennetot Pruvot and Estermann 2017). This approach significantly undermines the financial sustainability of universities in the long run and poses new risks, such as university's defaults on debt. In other words, the university's capacity to interact with the market should not be compromised by the lack of public support for its key goals and operations.

\footnotetext{
${ }^{4}$ The UK higher education system consists of four sub-systems (England, Northern Ireland, Scotland and Wales).

${ }^{5}$ Luxembourg, Latvia and the United Kingdom (England) are part of the high cluster scoring between 81 and $100 \%$.
} 


\section{Opportunity No. 3: Academic Autonomy for Greater Efficiency}

Another important finding is that academic autonomy affects not only the effectiveness of institutions but also their efficiency. In particular, the ability to design the content of degree programmes is considered the most important indicator for effectiveness across all autonomy dimensions and, at the same time, it is ranked among the top 3 for efficiency. Flexibility in introducing content based on the principles of student-centred and research-based learning largely supports the effectiveness of learning and teaching and, more generally, of higher education institutions (EFFECT 2019). Furthermore, the ownership of curriculum design can foster efficiency by using new modes of learning and teaching enabled by technology, helping institutions serve broader and, potentially, larger groups of learners with diverse needs. The appropriate investment in technology, student support and scaffolding, as well as teacher training remain, however, critical to the effective and efficient use of technology in curriculum design. Other modes of delivery and learning experience such as group work, mobility or work placements can further enhance both efficiency and effectiveness of study programmes. Finally, the ability to design content of degree programmes is an ultimate pre-condition for developing shared study courses and engaging in institutional collaboration in teaching and learning.

Furthermore, the capacity to introduce and terminate programmes has proven to be particularly important for efficiency. This finding has to be seen in view of the need for adapting the academic offer to the evolving needs of learners and employers, reducing course duplication and optimising the programme portfolio at institutional or faculty level. Any increase in autonomy in this respect requires that proper internal quality culture and accountability mechanisms are put in place. The gradual shift towards institutional accreditation — rather than programme-based accreditation - is in this respect a positive step forward both for academic autonomy and institutional efficiency.

Opportunity No 4: Organisational Autonomy for Greater Efficiency and Effectiveness Organisational autonomy is found to be more important for effectiveness than for efficiency. While none of the organisational autonomy indicators appears in the top 10 for efficiency, the ability to decide on the selection criteria and procedures for the executive head and the capacity for universities to decide on their internal academic structures are ranked high for effectiveness. Expert opinions particularly differ on the level of impact of some organisational autonomy indicators on efficiency and effectiveness, particularly the ability to decide on the dismissal procedure of the executive head and to set the term of office for the executive head.

The above findings acknowledge the expected importance of framework leadership provisions for effectiveness and show that it can be harder to connect the high-level organisational architecture (e.g. the ability to set the term of office for the executive head) to efficiency.

Yet, it has been previously shown that the institutional efficiency agenda largely depends on university leaders' ability to approach these topics strategically and operationally, to secure internal support and to mobilise resources to invest in modern capabilities and skilled staff in order to reap the benefits of efficient and effective uni- 
versity management (Estermann and Kupriyanova 2019). In this context, we interpret the above finding as a need to provide illustration on how various organisational and governance provisions, especially, institutional leadership arrangements can impact efficiency in concrete terms.

Thus, flexibility in defining the selection criteria for the executive head allows universities to decide on the appropriate profile and the key competences which might include, among others, the experience in change management, efficiency and effectiveness.

Furthermore, studying university merger management processes, which involve the conceptual work defining the organisation of the university activities in the field of learning, teaching and research (underpinned by the capacity to decide on internal academic structures), shows that universities often choose to revisit their academic structures not only with the intention to facilitate desirable developments such as interdisciplinarity, greater interaction with external stakeholders, stronger alignment with strategic priorities of the institution and more visible connection to the ecosystem, but also take it as a chance to review the existing structures and processes from the perspective of their efficiency (Bennetot et al. 2015).

Collaborating with external members of governing bodies is a proven way for universities to make efficiency part of their accountability mechanisms given that the ability to include and select external members in governing bodies can help universities critically review and report on their activities. It could also bring some additional expertise in efficiency and effectiveness from the outside and secure support of governing bodies for institutional efficiency strategies and operational plans. The relatively low impact of this indicator on efficiency might be due to the fact that, while it has become frequent for universities throughout Europe to include external members in their governing bodies, their capacity to select such members still remains limited, with public authorities often having a decisive role in the matter or making up for a significant part of the external members themselves (Bennetot Pruvot and Estermann 2018).

Surprisingly, the capacity to create legal entities was found to have one of the lowest impacts on both efficiency and effectiveness, with a rather high differentiation of expert views. Yet, it is one of the key factors for universities to engage in shared services, outsourcing or similar partnership arrangements. The experience of UK universities shows that creating university subsidiaries that manage specialised services for one or several institutions has a potential to foster quality and economic efficiencies in various fields such as facility management, ICT, HR, finance and student services as well as to provide an additional source of income for higher education institutions (e.g. Universities UK 2015). This is another area of organisational autonomy which deserves further attention and investigation in the follow-up study, taking into consideration the diverse capacity of universities to engage in such types of activities in different countries.

These opportunities provide an illustration of the impact of autonomy on efficiency and effectiveness which needs to be further explored. It is also important to stress that any regulatory reform aimed at enhancing university autonomy has to be driven by a broader set of considerations and objectives in a wider national context and 
go beyond the discussed needs in efficiency and effectiveness. They should also be accompanied by the appropriate formal and voluntary accountability mechanisms based on the principles of equity, fairness, and transparency.

\section{Conclusions}

The findings support some of our original hypotheses about the importance of autonomy for efficiency and effectiveness while casting new light on certain elements that have received little consideration so far. Views drawn from university leadership and top management show an acute awareness of the complex relationship between autonomy, efficiency and effectiveness in higher education. They confirm earlier observations derived from the USTREAM project that efficiency is by no means a matter of cutting costs in a rigid structure but rather a question of exploiting opportunities to improve processes and deliver better teaching and research outcomes. Thus, what universities see as essential for efficiency and effectiveness is the capacity to manage funds internally, select and advance their staff in an adequate way and design their academic offer to match the analysed needs. In a nutshell, these are the conditions necessary for an institution to develop a strategic profile and position itself vis-à-vis partners, competitors, funders and students in an increasingly fast-changing complex environment.

Our pilot results confirm the relevance of a bigger analysis involving a larger and more diverse sample representing different types of higher education institutions from a broader set of countries in Europe to validate the established patterns. Combined with the country- specific information from the University Autonomy Scorecard, it could offer new meaningful insights into the national regulatory reforms from the perspectives of efficiency and effectiveness.

Acknowledgements We are most grateful to twelve experts and institutional practitioners who supported our study and helped us assess the impact of various autonomy indicators on efficiency and effectiveness. This study would not have been possible without the engagement of Ingrid BengtssonRijavec, Chief Financial Officer, Malmö University, Sweden; Giuseppe Colpani, Director General, University of Rome Tor Vergata, Italy; Steinunn Gestsdóttir, Pro-Rector of Academic Affairs and Development, University of Iceland; Mihai Girtu, Vice-Rector for Strategy in Research, Development and Innovation, Ovidius University of Constanţa, Romania; Koen Goethals, Rector, University College Ghent, Belgium; Esa Hämäläinen, Head of Administration, University of Helsinki, Finland; Paulo Vargas Moniz, Professor, University of Beira Interior; Portugal, Kestutis Petrikonis, ViceRector for Studies, Lithuanian University of Health Sciences, Lithuania; Peter Riedler, Vice-Rector for Financial Affairs, Resources and Location Development, University of Graz, Austria; Remco Smulders, Secretary to the Board, the Association of Universities in the Netherlands (VSNU); Jerzy Woznicki, President, Polish Rectors Foundation, Poland; Arturs Zeps, Vice-Rector for Strategic Development, Riga Technical University, Latvia. Finally, we would like to thank the HUMANE, the Heads of University Management \& Administration Network in Europe, for their collaboration in identifying the experts for this study. 


\section{References}

Antony, J. (2017). Lean Six Sigma for higher education. International Journal of Productivity and Performance Management, 66(5), 574-576. https://doi.org/10.1108/IJPPM-03-2017-0063.

Balzer, W. K. (2010). Lean Higher Education: Increasing the Value and Performance of University Processes, New York: Productivity Press.

Balzer, W., Brodke, M. \& Kizhakethalackal, E. (2015). Lean higher education: successes, challenges, and realizing potential. International Journal of Quality \& Reliability Management, 32(9), 924-933.

Bennetot Pruvot, E., Claeys-Kulik, A. \& Estermann, T. (2015). Designing Strategies for Efficient Funding of Universities in Europe - DEFINE Final Publication, Brussels: European University Association. https://eua.eu/downloads/publications/designing\%20strategies\%20for $\% 20$ efficient $\% 20$ funding $\% 20$ of $\% 20$ universities $\% 20$ in $\% 20$ europe $\% 20$ define.pdf, accessed February 12, 2020.

Bennetot Pruvot, E. \& Estermann T. (2017). University Autonomy in Europe III. The Scorecard 2017: Brussels, European University Association.

Bennetot Pruvot, E. \& Estermann T. (2018). niversity Governance: Autonomy, Structures and Inclusiveness. In A. Curaj, L. Deca \& R. Pricopie (Eds.), European Higher Education Area: The Impact of Past and Future Policies (pp. 619-638). Cham: Springer. https://link.springer.com/content/pdf/ 10.1007\%2F978-3-319-77407-7_37.pdf, accessed February 12, 2020.

Bennetot Pruvot, E., Estermann, T. \& Kupriyanova, V. (2017). Public Funding Observatory Report 2017, Brussels: European University Association. https://eua.eu/downloads/publications/euapfo-report-december-2017.pdf, accessed February 12, 2020.

Bennetot Pruvot, E., Estermann, T. \& Lisi, V. (2018). Public Funding Observatory Report (2018), Brussels: European University Association.

Bovens, M. (2006). Analysing and Assessing Public Accountability. A Conceptual Framework. European Governance Papers (EUROGOV) No. C-06-01. https://dspace.library.uu.nl/bitstream/ handle/1874/234842/Analysing+and+Assessing+Public+Accountability1.pdf?sequence=1, accessed February 12, 2020.

Doman, M. S. (2011). A new lean paradigm in higher education: a case study, Quality Assurance in Education 19(3), 248-262.

EFFECT (2019). Promoting a European Dimension to Teaching Enhancement: A Feasibility Study from the European Forum for Enhanced Collaboration in Teaching (EFFECT) Project, Brussels: European University Association.

Estermann, T. (2017) Why university autonomy matters more than ever. University World News, 7 April. www.universityworldnews.com/post.php?story=20170404132356742, accessed February 12, 2020.

Estermann, T., Kupriyanova, V. \& Casey, M. (2018). Efficiency, Effectiveness and Value for Money: Insights from Ireland and Other Countries, Brussels: European University Association.

Estermann, T. \& Kupriyanova, V. (2019). Efficiency, Effectiveness and Value for Money at Universities - A USTREAM Report, Brussels: European University Association. https://eua.eu/component/ attachments/attachments.html?id=2404, accessed February 12, 2020.

Estermann, T. \& Nokkala, T. (2009). University Autonomy in Europe I: Exploratory Study, Brussels: European University Association.

19 European Forum for Enhanced Collaboration in Teaching (2019). Ten European Principles for the Enhancement of Learning and Teaching, Brussels: European University Association. https:// eua.eu/downloads/content/ten\%20uropean $\% 20$ principles $\% 20$ for $\% 20$ the $\% 20$ enhancement $\% 20$ of\%20learning\%20and\%20teaching16102017.pdf, accessed February 12, 2020.

Jongbloed, B., Enders, J. \& Salerno, C. (2008). Higher education and its communities: Interconnections, interdependencies and a research agenda. Higher Education, 56, 303-324.

Levacic, R. (2002). Efficiency, Equity and Autonomy'. In T. Bush \& L. Bell (Eds.), The Principles and Practices of Educational Management. Paul Chapman Publishing. 
Salerno, C. S. (2003). What we know about the efficiency of higher education institutions: the best evidence. Enschede: Center for Higher Education Policy Studies (CHEPS).

Scott, J. C. (2006). The mission of the University: medieval to postmodern transformations. The Journal of Higher Education, 77(1), 1-39.

Trow, M. (1996). Trust, Markets and Accountability in Higher Education: A Comparative Perspective. UC Berkeley: Center for Studies in Higher Education. https://escholarship.org/uc/item/ 6q21h265, accessed February 12, 2020.

Universities UK (2015). Efficiency, Effectiveness and Value for Money. www.universitiesuk.ac.uk/ policy-and-analysis/reports/Documents/2015/efficiency-effectiveness-value-for-money.pdf, accessed February 12, 2020.

Open Access This chapter is licensed under the terms of the Creative Commons Attribution 4.0 International License (http://creativecommons.org/licenses/by/4.0/), which permits use, sharing, adaptation, distribution and reproduction in any medium or format, as long as you give appropriate credit to the original author(s) and the source, provide a link to the Creative Commons license and indicate if changes were made.

The images or other third party material in this chapter are included in the chapter's Creative Commons license, unless indicated otherwise in a credit line to the material. If material is not included in the chapter's Creative Commons license and your intended use is not permitted by statutory regulation or exceeds the permitted use, you will need to obtain permission directly from the copyright holder.

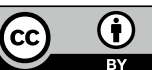

